\title{
SIMULATION OF COFFEE FRUIT DRYING USING COMPUTATIONAL FLUID DYNAMICS
}

\author{
Rudney Amaral ${ }^{1}$, Ednilton Tavares de Andrade², Francisco Carlos Gomes ${ }^{3}$, \\ Flávio Meira Borém ${ }^{4}$, Isabela Avila Lemos ${ }^{5}$, Camila de Almeida Dias ${ }^{6}$
}

(Received: June 08, 2018; accepted: August 15, 2018)

\begin{abstract}
Drying is a fundamental step in post-harvest handling of coffee because moisture content at the end of drying affects several important aspects, such as sensory quality, storability, and color of the fruit coffee. Within this context, the aim of this study is to determine water distribution within the natural coffee fruit during and at the end of the drying process. For that purpose, simulations were made through finite elements using computational fluid dynamics. Experimental data on moisture content of coffee fruit in the "cherry" stage were collected during drying, which was carried out at a temperature of $40^{\circ} \mathrm{C}$ and relative humidity of $25 \%$ to 0.18 decimal l(dry basis - d.b.) to compare the results of the experiment with the results of the simulations. Ten mathematical models of the drying process were developed for the collected data. The two-term exponential model best fit the data. The results of the simulations in computational fluid dynamics were compared to the results from experimental drying, and a satisfactory fit was obtained. The effective diffusivity coefficient $\left(\mathrm{D}_{\text {eff }}\right)$ was developed for the model proposed, obtaining the value of $2.87 \times 10^{-11} \mathrm{~m}^{2} \mathrm{~s}^{-1}$. At the end of drying, the model exhibited $57.1 \%$ of the projection area of the coffee fruit with moisture content below 0.18 decimal (d.b.). Thus, the model can be used for other applications.
\end{abstract}

Index terms: Moisture content, distribution, natural coffee, finite elements, diffusion.

\section{SIMULAÇÃO DA SECAGEM DE FRUTOS DE CAFÉ UTILIZANDO FLUIDODINÂMICA COMPUTACIONAL}

\begin{abstract}
RESUMO: A secagem é uma importante etapa da pós-colheita do café, visto que o teor de água ao final da secagem influencia questões importantes como qualidade sensorial, armazenabilidade e cor dos frutos de café. Mediante isso, a determinação da distribuição do teor de água no interior de um fruto de café natural durante e ao final do processo de secagem é o objetivo desse trabalho, onde foram realizadas simulações por meio de elementos finitos, utilizando a fluidodinâmica computacional. Foram coletados dados experimentais de teor de água durante a secagem de frutos cereja a qual foi realizada a uma temperatura de $40^{\circ} \mathrm{C}$ e umidade relativa de $25 \%$ e até que os frutos atingissem 0,18 decimal (b.s.) visando a validação do modelo. Foram ajustados aos dados coletados dez modelos matemáticos de secagem. O modelo Exponencial de Dois Termos foi o que melhor se ajustou aos dados. Os resultados das simulações em fluidodinâmica computacional foram ajustados aos resultados da secagem experimental, obtendo um ajuste satisfatório. O coeficiente de difusividade efetivo $\left(\mathrm{D}_{\text {eff }}\right)$ foi ajustado ao modelo proposto obtendo-se o valor de $2,87 \times 10^{-11} \mathrm{~m}^{2} \mathrm{~s}^{-1}$. Ao final da secagem, o modelo apresentou $57,1 \%$ da área de projeção do fruto de café com teor de água abaixo de 0,18 decimal (b.s.). Desta forma, o modelo pode ser utilizado para outras aplicações.
\end{abstract}

Termos para indexação: Teor de água, distribuição, café natural, elementos finitos, difusão.

\section{INTRODUCTION}

Coffee has a prominent position in Brazilian grain production, with 349,9 million dollars in exports, according to the Informe Estatístico do Café (2018).

The drying stage is fundamental in coffee to prevent the growth of microorganisms and fermentations that can compromise the quality of newly-harvested coffee, which has high moisture content and uneven maturity of the coffee fruit (berries) (RESENDE et al., 2009). The temperature of the coffee fruit must be strictly controlled because an excessive increase in temperature greatly affects its quality. Coffee should be dried at a temperature of $40^{\circ} \mathrm{C}$ for this operation not to affect beverage aroma and flavor (BORÉM, 2008).
Air flow during coffee drying has an effect only at the beginning of drying (Burmester; Eggers, 2010). In drying coffee fruit at low relative humidity, an increase in temperature brings about an increase in the effective diffusivity coefficient $\left(\mathrm{D}_{\text {eff }}\right)$, which ranges from 1.908 to $3.721 \times 10^{-11} \mathrm{~m}^{2}$ $\mathrm{s}^{-1}$, as well as in drying rate (Alves, et al. 2013).

Nilnont et al., (2012) modeled drying in parchment coffee through finite elements. Through this modeling, they obtained a model sufficient for predicting moisture content during the drying process. According to the authors, the twodimensional model provides better understanding of transport processes in different components of parchment coffee. The mean values of the coefficient of liquid diffusion of the coffee bean

1,2,3,4,5,6Universidade Federal de Lavras/UFLA - Departamento de Engenharia/DEG - Cx. P. 3037 - 37.200-000 - Lavras - MG rudneymec@yahoo.com.br, ednilton@deg.ufla.br, fcgomes@deg.ufla.br, flavioborem@gmail.com, isa_lemosti@hotmail.com, camila.almeidadias@gmail.com 
and of the coefficient of liquid diffusion of the parchment found by the authors are $7.173 \times 10^{-}$ ${ }^{10}$ and $6.737 \times 10^{-13} \mathrm{~m}^{2} \mathrm{~s}^{-1}$, respectively.

During the process of drying agricultural products, conditions are considered isothermal, and water transfer is restricted to the surface of the product (Bergman, et al. 2011).Thus, the aim of this study was to determine the distribution of moisture content within natural coffee fruit during and at the end of the drying process. A computational fluid dynamic model was used to describe the process of heat and matter transfer within the fruit. This model allows analysis of the liquid diffusion rate in the coffee fruit during drying, as well as the distribution of moisture content at the end of drying.

\section{MATERIALS AND METHODS}

Mature or "cherry" coffee fruit (Coffea arabica L. cv. Catuai Vermelho) was used. The fruit was harvested manually. Fruit with lower specific weight (shriveled, floaters, etc.) were removed through separation in water. The fruit had average moisture content of 2.11 decimal (dry basis - d.b.) at the beginning of drying. The moisture content of the coffee fruit was determined by the standard method of ISO 6673 (INTERNATIONAL ORGANIZATION for STANDARDIZATION ISO, 2003).

Before the beginning, during, and at the end of mechanical drying, the main dimensions of 10 samples of the coffee fruit were measured. These measurements were made with a digital caliper rule with $0.01 \mathrm{~mm}$ readability, resulting in the mean dimensions shown in Table 1.

The volume of the coffee berry (V) was calculated by equation 01 . The coffee berries were considered as oblate spheroids. The equivalent radius of the coffee berries was also calculated, defined as the radius of a sphere with volume equivalent to the volume of the berry.

$$
\mathrm{V}=\frac{4 \pi(\mathrm{abc})}{3}
$$

In which $\mathrm{V}$ is the volume at each level of moisture content $\left(\mathrm{m}^{3}\right)$, $a$ is the length $(\mathrm{m}), \mathrm{b}$ is the width $(\mathrm{m})$, and $\mathrm{c}$ is the thickness $(\mathrm{m})$.

The samples were weighed on a precision digital balance with $0.01 \mathrm{~g}$ readability. The true specific weight before drying the fruit was calculated by the simple ratio between weight and volume, as well as the true specific weight at the end of drying. The true mean specific weight of the fruit during the drying process was also calculated.

The system for drying the samples was composed of an air conditioning unit coupled to a fixed bed dryer (Figure 1).

The laboratory air conditioning system (LACS) was used to control the characteristics of the drying air according to the model proposed by Fortes et al. (2006). This equipment allows control of the flow, temperature, and relative humidity of the drying air and is composed of a cooling system with three air conditioning units. The dryer included four removable square trays perforated at the bottom, with sides of $0.3 \mathrm{~m}$ and depth of $0.1 \mathrm{~m}$, located over a plenum to make the air flow uniform. The temperature of the drying air was measured in the plenum, under the perforated trays, by thermocouples connected to universal controllers (Novus N1100). A digital hygrometer inserted in the plenum measured the relative humidity of the drying air. A frequency inverter (Weg CFW-10) controlled the rotation of the centrifugal fan that blows the heated air into the plenum; it thus regulated the air flow.

The procedure began by completely filling the perforated-bottomtrays. For each hour of drying, the trays were removed from the dryer and weighed on an analytical balance with $0.01 \mathrm{~g}$ readability. This procedure was repeated until the fruit was dried to 0.18 decimal (d.b.); the standard laboratory oven method (BRASIL, 2009) was used to determine the moisture content of the fruit. Total drying time was 109 hours. The tray position was revolved $90^{\circ}$ every hour to minimize possible differences of temperature and air flow among the perforated-bottomtrays.

TABLE 1 - Dimensions of natural coffee fruit

\begin{tabular}{lll}
\hline Axis & Dimension $(\mathrm{m})$ & Dimension used $(\mathrm{m})$ \\
Length (a) & $1.4 * 10^{-3}$ & $7 * 10^{-3}$ \\
Width (b) & $1.1 * 10^{-3}$ & $5.5^{*} 10^{-3}$ \\
Thickness (c) & $0.9^{*} 10^{-3}$ & $5.5^{*} 10^{-3}$ \\
\hline
\end{tabular}




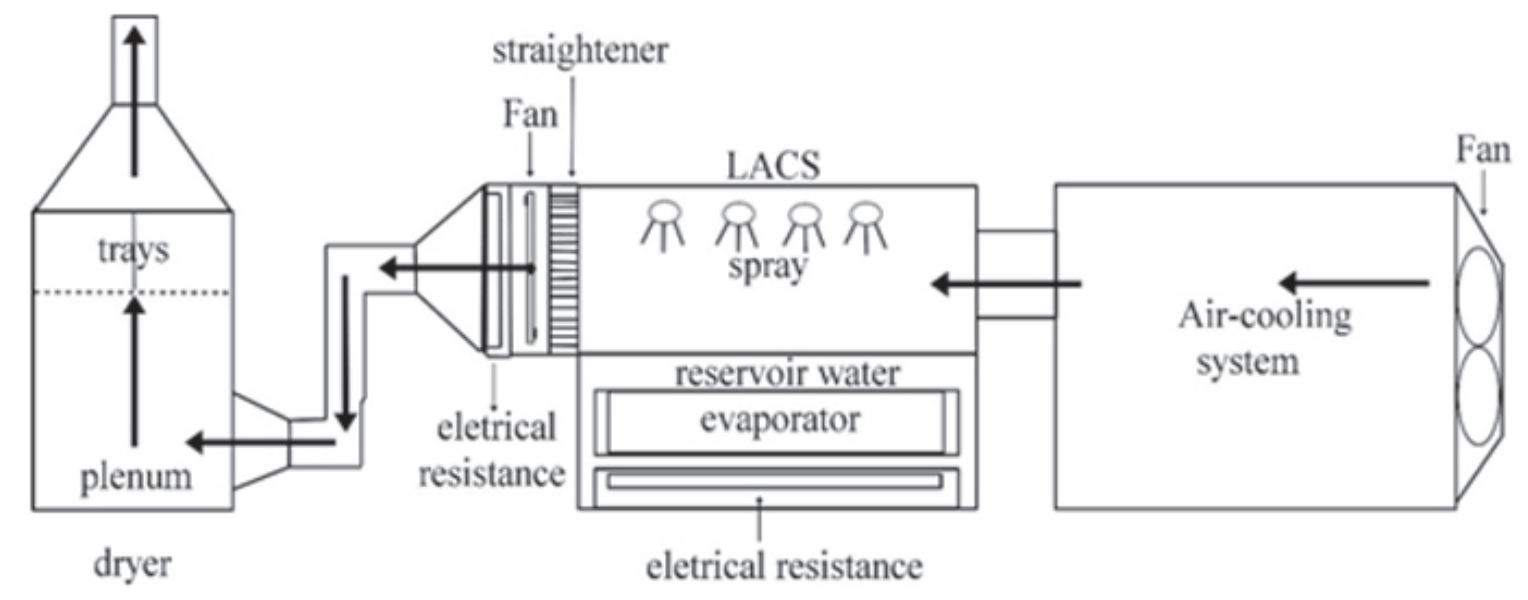

FIGURE 1 - System used in mechanical.

The air flow variables of the drying air were kept constant throughout the procedure the temperature was $40^{\circ} \mathrm{C}$, relative humidity was $25 \%$ and air speed was $0.33 \mathrm{~m} \mathrm{~s}^{-1}$, for a flow of 20 $\mathrm{m}^{3} \mathrm{~min}^{-1} \mathrm{~m}^{-2}$.

For the drying conditions of this study, the equilibrium moisture content of the fruit was calculated using the model proposed by Afonso Júnior (2001) and cited by Borém (2008) for "cherry" fruit (Equation 2).

$E M C=\left(2.0222+(0.0288 T)-\left(18.7397 R H^{86181}\right)\right)^{-2.1385}$

In which is the equilibrium moisture content (d.b.), is the drying air temperature $\left({ }^{\circ} \mathrm{C}\right)$, and is the relative humidity of the drying air (decimal).

The moisture ratio was calculated from fitting equation (3) to the data observed using the STATISTICA ${ }^{\circledR} 5.0$ (Statsoft, Tulsa, USA) software. The moisture ratio (MR) is essential for describing different drying models in a thin layer. Equation (3) is the analytical solution for Fick's second law, considering the geometric form as spherical and considering the surface contour condition as known (BROOKERet al., 1992).

$$
M R=\frac{M-E M C}{M_{i}-E M C}=\frac{6}{\pi^{2}} \sum_{n=1}^{\infty} \frac{1}{n^{2}} \exp \left[-\frac{n^{2} \cdot \pi^{2} \cdot \text { D.t }}{9} \cdot\left(\frac{3}{R}\right)^{2}\right]
$$

in which MR is the moisture ratio of the product, adimensional; $\mathrm{M}$ is the moisture content of the product, decimal (d.b.); EMC is the equilibrium moisture content of the product, decimal (d.b.); $\mathrm{M}_{\mathrm{i}}$ is the initial moisture content of the product, decimal (d.b.); $\mathrm{D}$ is the effective diffusivity coefficient $\left(\mathrm{m}^{2} \mathrm{~s}^{-1}\right)$, and $\mathrm{R}$ is the equivalent radius of the coffee fruit (m);

The mathematical models disposed in Table 2 by Equations (4) to (14) were fitted to the experimental data of coffee drying.

The choice of the best model was based on the statistical parameters: standard deviation of the estimate (SE), mean relative error (P), coefficient of determination (R2), and the chisquare, calculated by equations 15 to 17 . in which $\mathrm{SE}$ is the standard deviation of the estimate (decimal), $\mathrm{Y}$ is the experimentally observed value, is the value calculated by the model, DFR is the number of degrees of freedom of the model, $\mathrm{P}$ is the mean relative error (\%), and $\mathrm{n}$ is the number of data observed.

For the purpose of understanding heat and mass transfer in coffee fruit during drying, the distribution of moisture content can be identified within the coffee berry by mathematical modeling. Under computational fluid dynamics, hypotheses can be analyzed more easily since computational fluid dynamics is a technique that has been used for evaluation of various physical phenomena using the finite element method. This technique is a set of computational tools based on numerical algorithms to solve and interpret problems in the flow of fluids (SCHNEIDER; MALISKA,2000).

For fluid flows, the mathematical model is based on equations of conservation of the amount of movement, conservation of mass, and conservation of energy. Analytical solution of these equations is only possible for very simple flows. 
TABLE 2 - Mathematical models used to predict drying.

\begin{tabular}{ll}
\hline Model & Equation \\
\hline Diffusion Approximation & $\mathrm{MR}=\mathrm{a} \cdot \exp (-\mathrm{k} \cdot \mathrm{t})+(1-\mathrm{a}) \cdot \exp (-\mathrm{k} \cdot \mathrm{b} \cdot \mathrm{t})$ \\
Two Term & $\mathrm{MR}=\mathrm{a} \cdot \exp \left(-\mathrm{k}_{0} \cdot \mathrm{t}\right)+\mathrm{b} \cdot \exp \left(-\mathrm{k}_{1} \cdot \mathrm{t}\right)$ \\
Two-Term Exponential & $\mathrm{MR}=\mathrm{a} \cdot \exp (-\mathrm{k} \cdot \mathrm{t})+(1-\mathrm{a}) \exp (-\mathrm{k} \cdot \mathrm{a} \cdot \mathrm{t})$ \\
Logarithm & $\mathrm{MR}=\mathrm{a} \cdot \exp (-\mathrm{k} \cdot \mathrm{t})+\mathrm{b}$ \\
Midili & $\mathrm{MR}=\mathrm{a} \cdot \operatorname{Exp}\left(-\mathrm{k} \cdot \mathrm{t}^{\mathrm{n}}\right)+\mathrm{b} \cdot \mathrm{t}$ \\
Newton & $\mathrm{MR}=\exp (-\mathrm{k} \cdot \mathrm{t})$ \\
Page & $\mathrm{MR}=\operatorname{Exp}\left(-\mathrm{k} \cdot \mathrm{t}^{\mathrm{n}}\right)$ \\
Modified Page & $\mathrm{MR}=\operatorname{Exp}\left(-(\mathrm{k} \cdot \mathrm{t})^{\mathrm{n}}\right)$ \\
Thompson & $\mathrm{MR}=\exp \left(\left(-\mathrm{a}-\left(\mathrm{a}^{2}+4 \cdot \mathrm{b} \cdot \mathrm{t}\right)^{0,5}\right) / 2 \cdot \mathrm{b}\right)$ \\
Verna & $\mathrm{MR}=\mathrm{a} \cdot \exp (-\mathrm{k} \cdot \mathrm{t})+(1-\mathrm{a}) \exp (-\mathrm{k} 1 \cdot \mathrm{t})$ \\
Wang and Singh & $\mathrm{MR}=1+\mathrm{at}+\mathrm{bt} \mathrm{t}^{2}$ \\
\hline
\end{tabular}

MR is the moisture ratio (dimensionless); $\mathrm{k}, \mathrm{k} 0, \mathrm{k} 1$ are drying constants ( $\mathrm{s}-1)$; $\mathrm{t}$ is the drying time (h); a, b, $\mathrm{n}$ are constants that depend on the nature of the product (dimensionless). (BROOKER et al., 1992; Corrêa et al., 2001; Alves et al., 2013; Filho et al., 2015).

$$
\begin{aligned}
& S E=\sqrt{\frac{\sum(Y-\hat{Y})^{2}}{D F R}} \\
& P=\frac{100}{n} \cdot \sum \frac{|Y-\hat{Y}|}{Y} \\
& \chi^{2}=\frac{\sum(Y-\hat{Y})^{2}}{D F R}
\end{aligned}
$$

To analyze real problems in which strong temporal variations and turbulence are found, numerical methods are used that are able to analyze flows in a general manner through discretization of the equations cited. Computational fluid dynamics is divided into three basic steps: the first is pre-processing, in which the geometry and the numerical mesh is generated and the contour conditions are defined; the second step is processing, which is solution of the mathematical equations using discretization; and the third step is post-processing in which the information, graphs, and analyses generated in the solution are visualized (SILVA et al., 2012).

According to Crank (1975), there is an analogy between thermal conduction and liquid diffusion. The mathematical theory of diffusion in isotropic bodies is based on the hypothesis that the transfer rate of a substance diffused through the unit area of a section is proportional to the gradient of concentration measured normally at the section. In an analogous manner, the transfer rate of heat through the unit area of a section is proportional to the temperature gradient measured normally at the section. Table 3 shows the analogy between the two processes:

The analogy between liquid diffusion and thermal conduction was used to develop the computational simulation of coffee drying using modeling by the commercial software ANSYS ${ }^{\circledR}$ $\mathrm{ED}^{\mathrm{TM}}$ (version 9.0) through programming in APDL (Ansys Parametric Design Language) language.

To carry out simulations, geometry that corresponds to one fourth of a coffee berry (axisymmetric) was chosen, as shown in Figure 2 , considering axial symmetry of the coffee berry. 
TABLE 3 - Analogy between liquid diffusion and thermal conduction.

\section{LIQUID DIFFUSION}

Occurs through random movements

Fick 1855

$\mathrm{D}$ is the diffusion coefficient

$\mathrm{C}$ is concentration of the substance

$F(t)=-D \partial C / \partial x$

\section{THERMAL CONDUCTION}

Occurs through random movements

Fourier 1822

$\mathrm{K}$ is thermal conductivity

is temperature

$F$ is the diffusive flux and/or heat flux
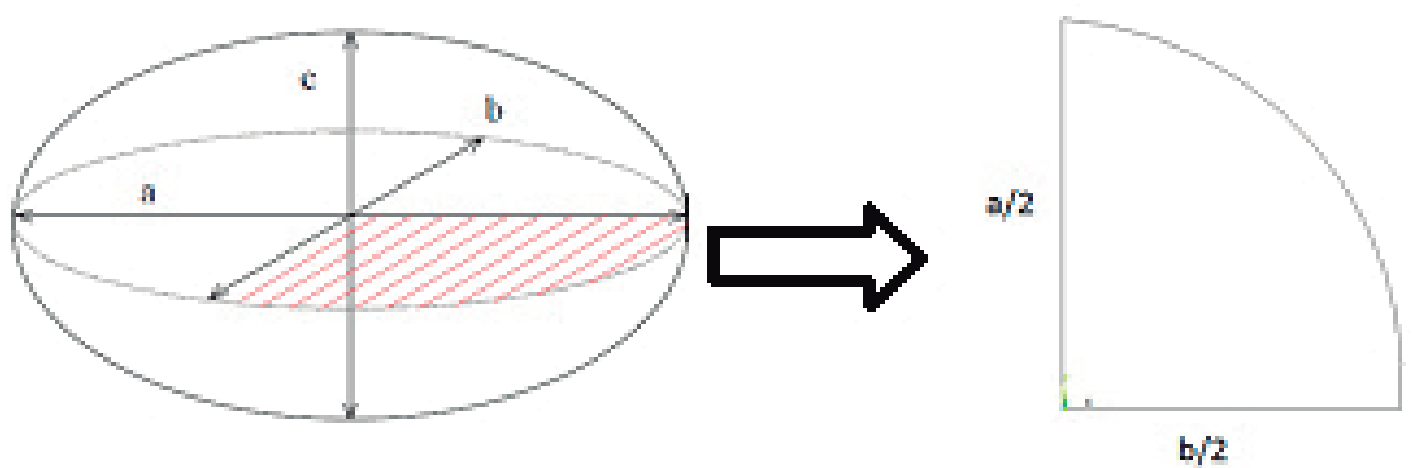

FIGURE 2 - Representation of a coffee berry as an oblate spheroid.

The main dimensions of "cherry" coffee fruit were measured with a digital caliper rule with $0.01 \mathrm{~m}$ readability. The main dimensions of a coffee berry are shown in Table 1 . The a and $\mathrm{b}$ values of $6.9132 \times 10^{-3} \mathrm{~m}$ and $5.7347 \mathrm{x}$ $10^{-3} \mathrm{~m}$, respectively, were used for the geometry implemented.

A thermal element called PLANE77 (Figure 3) was chosen, which is a two-dimensional quadrangular element with eight nodes applicable to two-dimensional thermal analyses according to Ansys (2011) to make up the computational mesh. The mesh was regular with its three sides divided into the same number of elements. This procedure divided the geometry presented into507 elements and 1600 nodes (Figure 4).

The initial conditions and the contour conditions were also defined in pre-processing.

The effective diffusivity coefficient $\left(\mathrm{D}_{\text {eff }}\right)$ used in the simulation was fitted to the real data to represent the experimental data.
The total fruit drying time in the computational model was 109 hours, which was the same time obtained experimentally with the fruit in order to dry to mean moisture content of 0.18 decimal (d.b.).

The initial condition used for solution of the problem was to apply the same concentration of moisture content to all the nodal points of the mesh. For that purpose, the initial concentration of moisture content was calculated at 861.55 $\mathrm{kg}\left(\mathrm{H}_{2} \mathrm{O}\right) \cdot \mathrm{m}^{-3}$. This value was obtained from the product of the fruit moisture content in dry basis and the specific weight of the fruit. This initial condition corresponds to moisture content of 2.11 decimal (d.b.). For the value of specific weight, its mean variation in time was considered, obtaining the value of $1305 \mathrm{~kg} \mathrm{~m}^{-3}$. The dry matter part of this specific weight was considered for use of the model $\left(408.3 \mathrm{~kg} \mathrm{~m}^{-3}\right)$. 


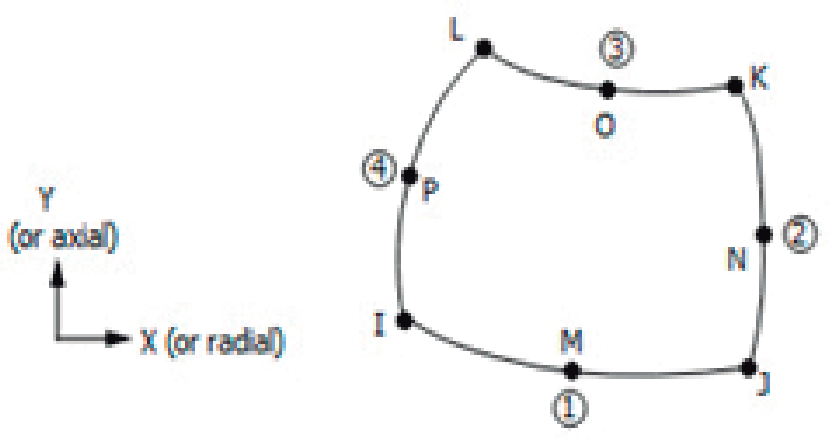

FIGURE 3 - PLANE77 element.

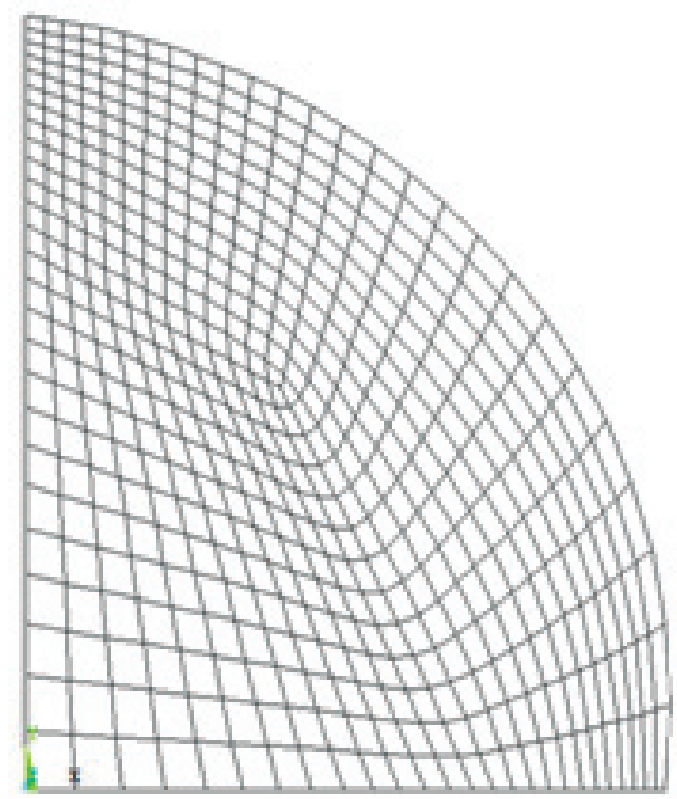

FIGURE 4 - Representation of the element mesh obtained in the model.

The concentration of equilibrium moisture content was applied on the outside surface of the fruit, represented by the arc in the geometry implemented in the simulations. The concentration of equilibrium moisture content is the product of the equilibrium moisture content of the coffee fruit (calculated by equation 02) and its specific weight. The value of the concentration of the equilibrium moisture content was calculated at $34.53 \mathrm{~kg}\left(\mathrm{H}_{2} \mathrm{O}\right) \cdot \mathrm{m}^{-3}$.

Considering the above, the source program was developed from the menu of commands available in the library of the Ansys ${ }^{\mathbb{B}}$ software, applying the initial conditions and contour conditions calculated. Thus, the problem of the process for removing water from the coffee fruit was resolved.
Through simulation, the nodal values of concentration of moisture content were obtained in each minute of the drying process, as well as the distribution of moisture content within the fruit. The simulation came to an end exhibiting 720 iterations in all.

To evaluate the efficiency of the model developed computationally in APDL language for liquid diffusion of the coffee fruit, the results of the model were compared to the results obtained experimentally. The moisture ratio curve for the two cases was compared.

The mean relative error $(\mathrm{P})$ was calculated by equation 16 from the drying curves obtained by the computational model in order to carry out statistical parameterization. 


\section{RESULTS AND DISCUSSION}

The mean calculated volume of the coffee berry before drying was $9.922 \times 10^{-5} \mathrm{~m}^{3}$. The mean measured weight of the coffee berry was $1.52 \mathrm{~g}$ and the true specific weight of the fruit before drying was $1540.69 \mathrm{~kg} \mathrm{~m}^{-3}$. At the end of drying, when the fruit had a moisture content of 0.18 decimal (d.b.), the true specific weight was $918.84 \mathrm{~kg} \mathrm{~m}^{-3}$, and the true mean specific weight during drying was $1305 \mathrm{~kg} \mathrm{~m}^{-3}$.

The initial equivalent ratio of the samples was $6.18 \times 10^{-3} \mathrm{~m}$, and the equilibrium moisture content was $8.458 \times 10^{-2}$ decimal (d.b.).

The moisture ratio according to time was calculated by equation (03). Figure 5 shows the comparison of the simulated values and the experimental values for the variation of the moisture ratio (MR) as a function of time by the two-term exponential model, which best fit the experimental data. In Table 4 are the values of the coefficient of determination $\left(\mathrm{R}^{2}\right)$, mean relative error $(\mathrm{P})$, standard deviation of the estimate (SE), chi-square and the constants of the twoterm exponential model. This model exhibited satisfactory values of the mean relative and estimated errors, as well as a high coefficient of determination $\left(\mathrm{R}^{2}\right)$. Values of mean relative error below $10 \%$ mean a good fit of data to the drying phenomenon according to Madamba et al. (1996) and confirmed by Mohapatra and Rao (2005).

The effective diffusivity coefficient $\left(\mathrm{D}_{\text {eff }}\right)$ was calculated at the value of $1.86 \times 10^{-11} \mathrm{~m}^{2} \mathrm{~s}^{-1}$. This result is corroborated by Alves et al. (2013), who found a variation of this coefficient from 1.908 to $3.721 \times 10^{-11} \mathrm{~m}^{2} \mathrm{~s}^{-1}$.

TABLE 4 - Coefficient of determination $\left(\mathrm{R}^{2}, \%\right)$, mean relative error $(\mathrm{P}, \%)$, standard deviation of the estimate $(\mathrm{SE})$, chi-square $\left(\chi^{2}\right)$, and the constants of the two-term exponential model.

\begin{tabular}{llllllcc}
\hline Temperature & \multicolumn{3}{c}{ Statistical parameter } & \multicolumn{3}{c}{ Constants of the model } \\
\cline { 2 - 7 } & $\chi^{2}$ & $\mathrm{P}$ & $\mathrm{SE}$ & $\mathrm{R}^{2}$ & $\mathrm{a}$ & $\mathrm{b}$ & $\mathrm{k}$ \\
\hline $40^{\circ} \mathrm{C}$ & 0.0004 & 0.73 & 0.022 & 99.99 & 30.467 & 0.9789 & -0.0302
\end{tabular}

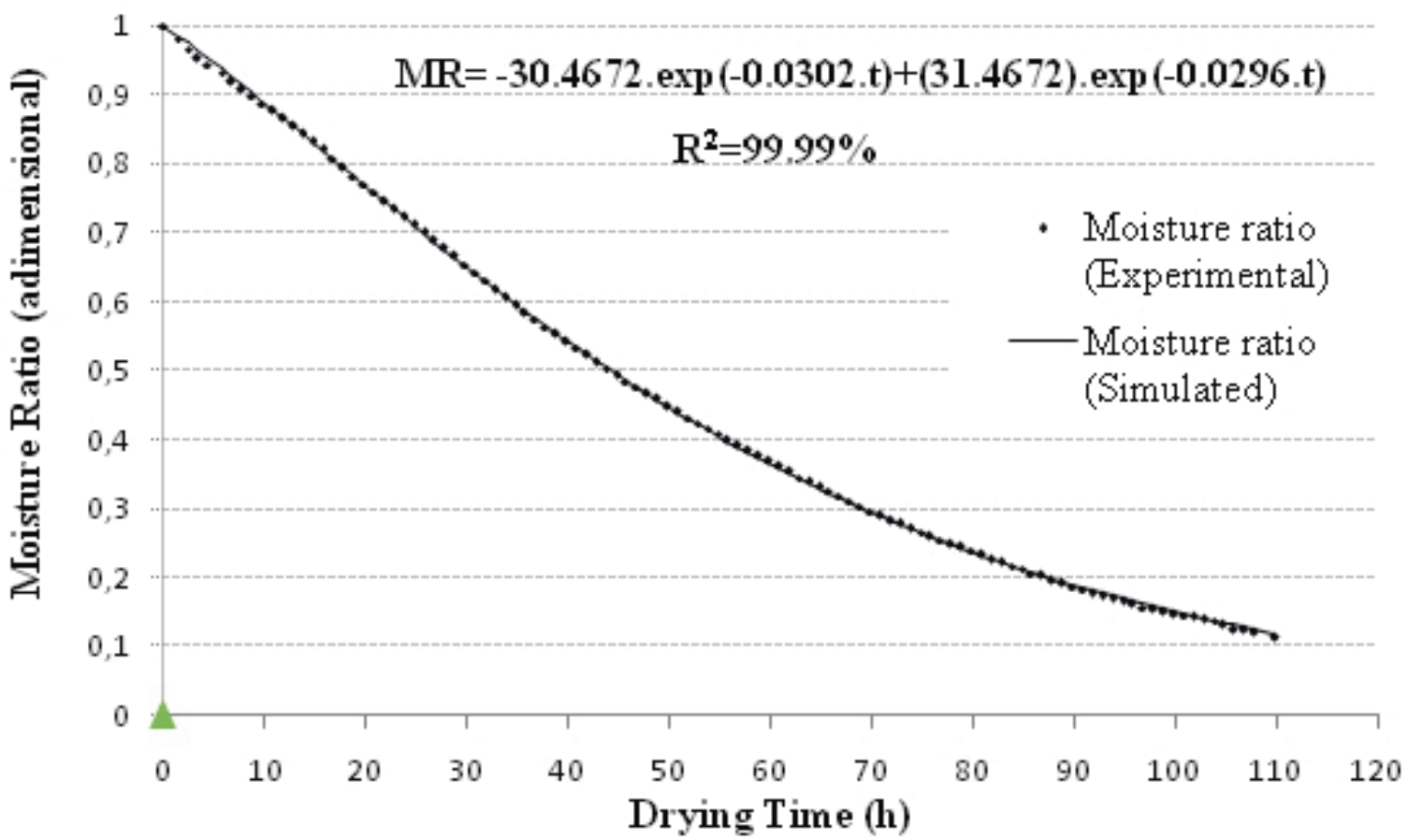

FIGURE 5 -Values of the experimental and simulated moisture ratio by the two-term exponential model for drying of coffee fruit as a function of time (h). 
The value obtained for the effective diffusivity coefficient $\left(\mathrm{D}_{\text {eff }}\right)$ that best fit the experimental data was $2.87 \times 10^{-11} \mathrm{~m}^{2} \mathrm{~s}^{-1}$. This value is in agreement with the results presented in the study of Isquierdo (2011), who studied the drying kinetics for natural coffees under different temperatures and relative humidities of the drying air and concluded that the effective diffusivity coefficient ranges from $1.460 \times 10^{-11}$ to $3.993 \mathrm{x}$ $10^{-11} \mathrm{~m}^{2} \mathrm{~s}^{-1}$. This is also in agreement with the result obtained by Alves et al. (2013), who obtained the effective diffusivity coefficient $\left(\mathrm{D}_{\text {eff }}\right)$ of water in coffee fruit ranging from $1.908 \times 10^{-11}$ to $3.721 \mathrm{x}$ $10^{-11} \mathrm{~m}^{2} \mathrm{~s}^{-1}$. The value obtained in a computational manner for the effective diffusivity coefficient $\left(\mathrm{D}_{\text {eff }}\right)$ is a mean value since the components of a coffee berry were not considered, such as the parchment. In fact, each component has a specific effective diffusivity coefficient $\left(\mathrm{D}_{\text {eff }}\right)$.
The knowledge of the distribution of water inside the fruit provides better drying, seeking mechanisms to accelerate the process without compromising its structure and quality, enabling the development of new forms and more efficient drying equipment. In addition, it is possible to obtain a better way of handling the drying in order to maintain the quality of the product with a less aggressive drying. Distribution of the moisture content within the coffee berry at the end of the drying process for the berries analyzed in this study is shown in Figure 6. Each color in the Figure indicates a range of concentration of moisture content.

The numbered areas in Figures 6 and 7were calculated, as well as the percentage of each one in relation to the area of the entire berry.

In Table 05, the approximate percentage of each area of Figure 07 is shown.

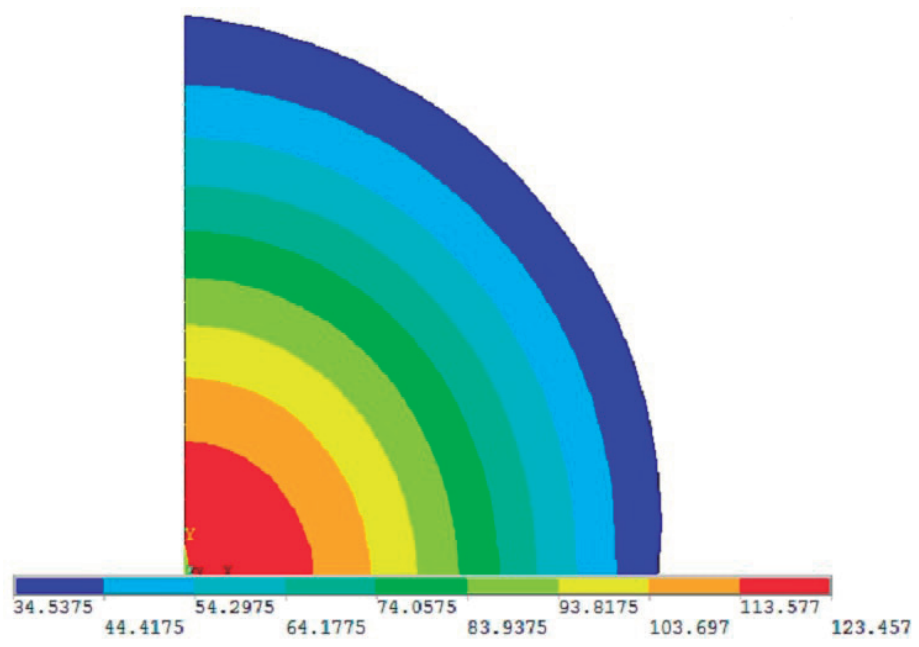

FIGURE 6 - Distribution of concentration of moisture content $\left[\mathrm{kg}\left(\mathrm{H}_{2} \mathrm{O}\right) \mathrm{m}^{-3}\right]$ resulting from simulation of drying of coffee fruit.

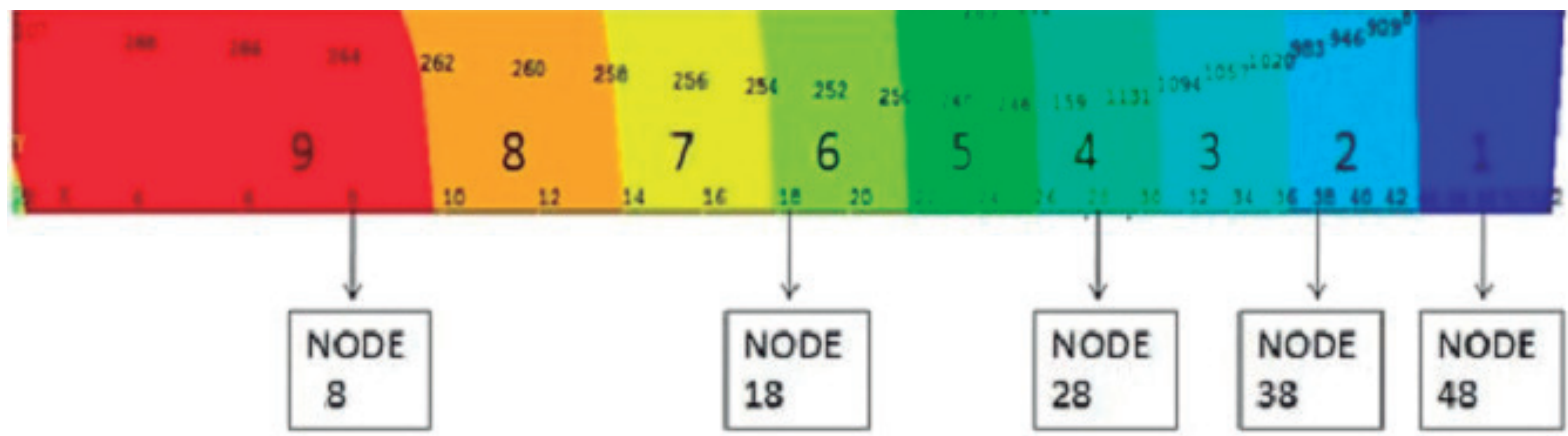

FIGURE 7 - Representation of the nodal points involved in each area on the $\mathrm{X}$ axis. 
TABLE 5 - Distribution of moisture content in different areas from the center to the outside extremity of the coffee berry after drying.

\begin{tabular}{lllll}
\hline No. & $\begin{array}{l}\text { Area } \\
\left(\mathrm{m}^{2}\right)\end{array}$ & $\begin{array}{l}\text { Equivalence } \\
(\%)\end{array}$ & $\begin{array}{l}\text { Water concentration } \\
\left(\mathrm{kg}\left(\mathrm{H}_{2} \mathrm{O}\right) \mathrm{m}^{-3}\right)\end{array}$ & $\begin{array}{l}\text { Moisture content decimal } \\
(\mathrm{d} . b .)\end{array}$ \\
1 & $2.09 \mathrm{E}-05$ & 16.4 & $34.54-44.42$ & $0.08-0.11$ \\
2 & $1.75 \mathrm{E}-05$ & 13.7 & $44.42-54.30$ & $0.11-0.13$ \\
3 & $1.67 \mathrm{E}-05$ & 13.1 & $54.30-64.18$ & $0.13-0.16$ \\
4 & $1.77 \mathrm{E}-05$ & 13.9 & $64.18-74.06$ & $0.16-0.18$ \\
5 & $1.21 \mathrm{E}-05$ & 9.5 & $74.06-83.94$ & $0.18-0.21$ \\
6 & $1.19 \mathrm{E}-05$ & 9.4 & $83.94-93.82$ & $0.21-0.23$ \\
7 & $1.12 \mathrm{E}-05$ & 8.8 & $93.82-103.70$ & $0.23-0.25$ \\
8 & $9.65 \mathrm{E}-06$ & 7.6 & $103.70-113.58$ & $0.25-0.28$ \\
9 & $9.72 \mathrm{E}-06$ & 7.6 & $113.58-123.46$ & $0.28-0.30$ \\
\hline
\end{tabular}

Area 1 (shown in blue) is the largest and the one that lost most water, as expected, because it is the outside surface of the berry. A band composed of the sum of areas $1,2,3$, and 4 is equivalent to $57.1 \%$ of the total area of projection of a coffee berry. In Table 04, the values of the range of concentration of moisture content in each area are shown. In areas from 1 to 4 , the highest concentration of moisture content is $74.06 \mathrm{~kg}\left(\mathrm{H}_{2} \mathrm{O}\right)$ $\mathrm{m}^{-3}$, equivalent to $0.18 \mathrm{decimal}$ (d.b.) of moisture content.

The evolution of the liquid diffusion process of moisture content in coffee fruit over the drying time is illustrated in Figures 08 and 09, for which each figure represents 24 hours of evolution of the liquid diffusion process.

Figures 8 and 9 show that evolution of the water diffusion process within the coffee berry is inversely proportional to drying time; that is, liquid diffusion is increasingly slower over time. This generates greater difficulty in removing water from the fruit at the end of drying, thus increasing the risks of losses in product quality. This is in agreement with several studies already described in the literature, such as the study of Saath et al. (2010).
Figure 10 shows the liquid diffusion that occurred within a coffee berry during simulation in vector format. The difficulty of removing water from the points nearest the center of the berry can be noted from the figure.

Figure 11 shows the values of concentration of moisture content $\left(\mathrm{kg}\left(\mathrm{H}_{2} \mathrm{O}\right) \mathrm{m}^{-3}\right)$ for some nodal points of the computational mesh as a function of time. From Figure 11, it can be observed that in the center of the berry, moisture content is higher. The line that represents the drying curve for nodal point 08 is very different from the drying curve of nodal point 48 . This occurs because nodal point 08 is at $0.12 \times 10^{-2} \mathrm{~m}$ from the center of the berry and nodal point 48 is at $0.54 \times 10^{-2} \mathrm{~m}$ from the center of the berry. In addition to the drying curves of nodal points 08 and 48, Figure 11 shows the drying curves for nodal points 18,28 , and 38 indicated in Figure 7.

The values of moisture ratio for the experimental data compared to the simulated data as a function of time are shown in Figure 12. The simulation carried out adequately represents coffee fruit drying. The experimental data and simulated data matched satisfactorily. Thus, the model can be used for other applications that require representation of this phenomenon. The mean relative error $(\mathrm{P})$ was $1.8 \%$, which is considered satisfactory. 

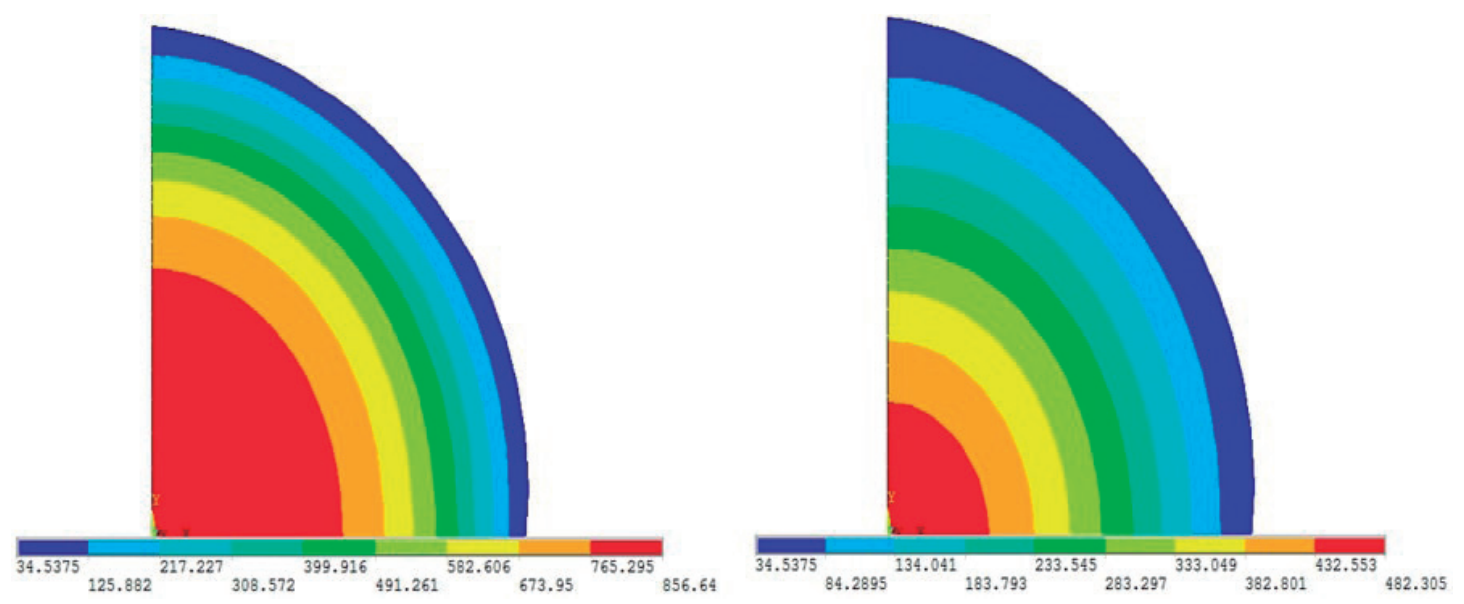

FIGURE 8 -Visualization of the field of moisture content for 24 and 48 hours of drying.
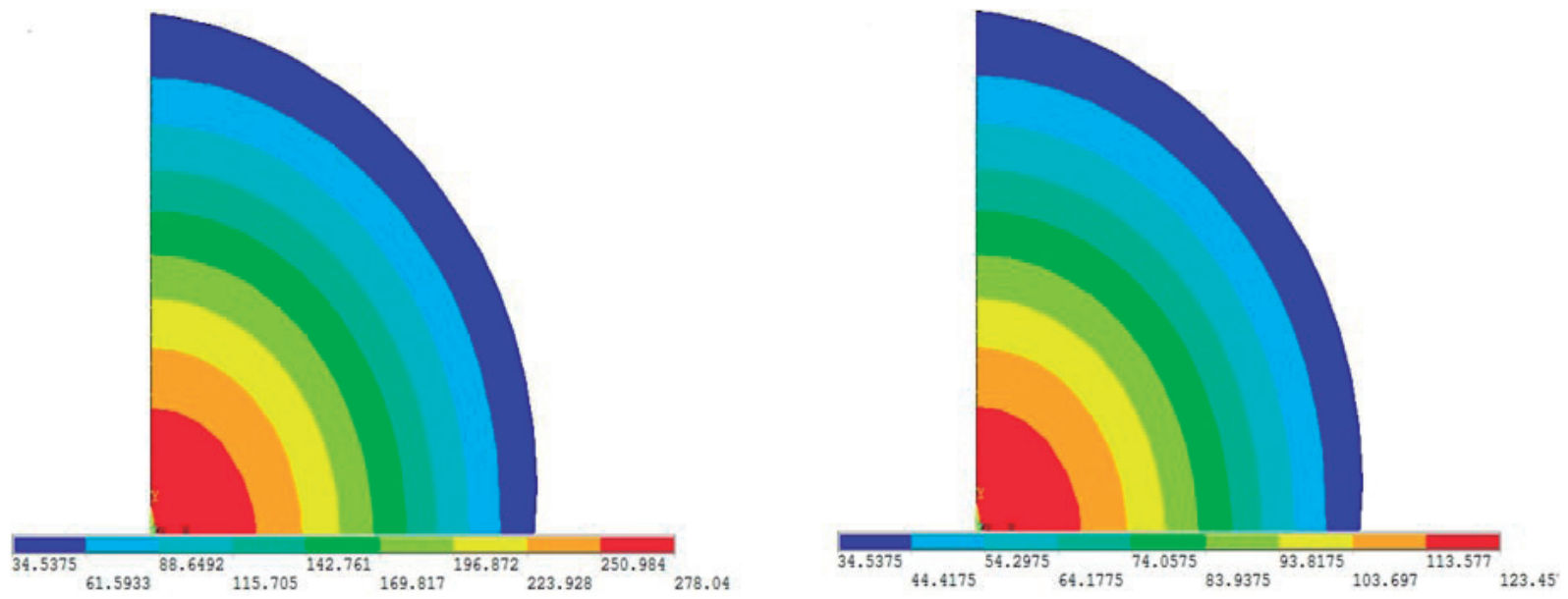

FIGURE 9 - Visualization of the field of moisture content for 72 and 96 hours of drying.

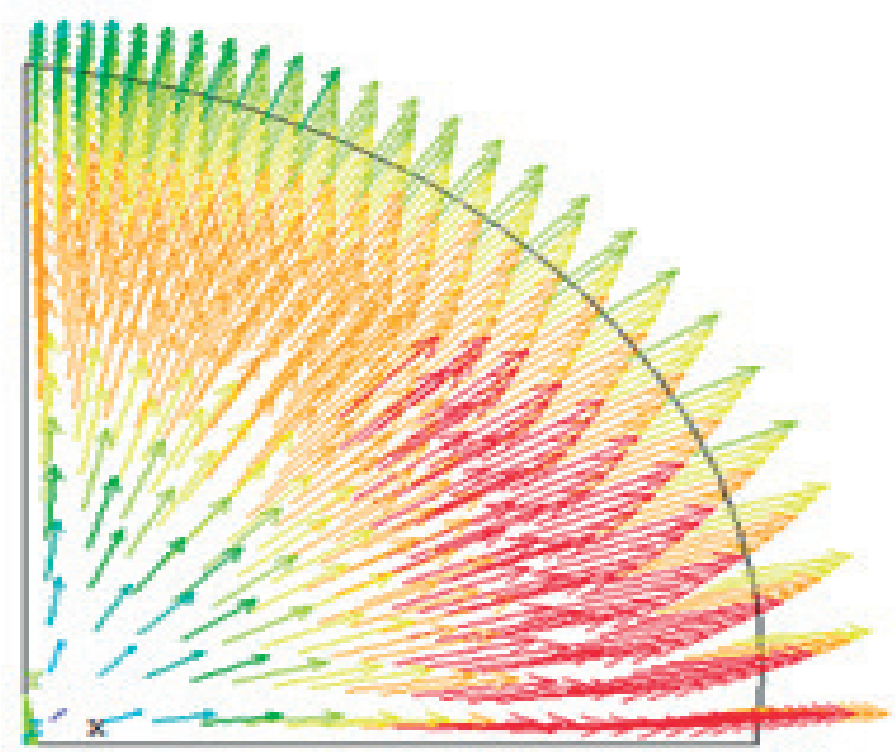

FIGURE 10 -Vector representation of liquid diffusion that occurred within the coffee berry. 

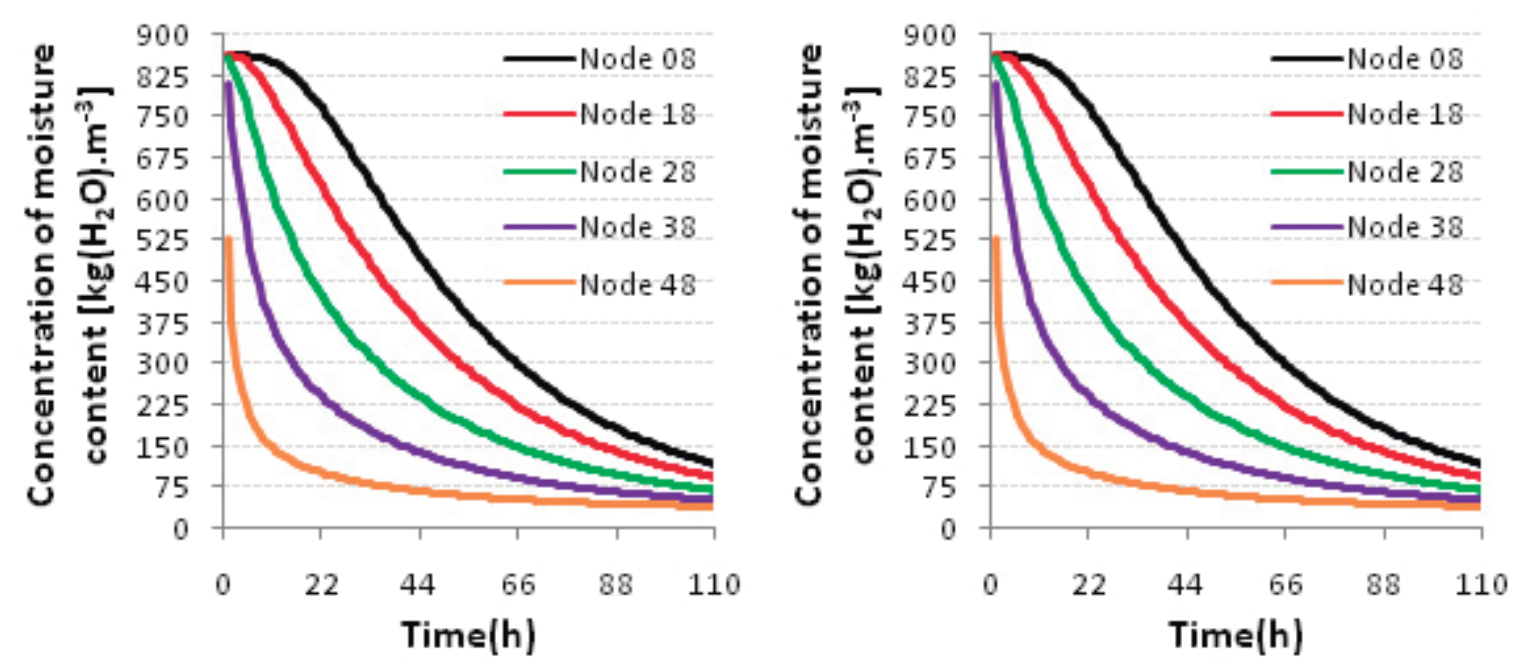

FIGURE 11 - Drying curves for some nodes chosen on the $\mathrm{X}$ axis of the geometry.

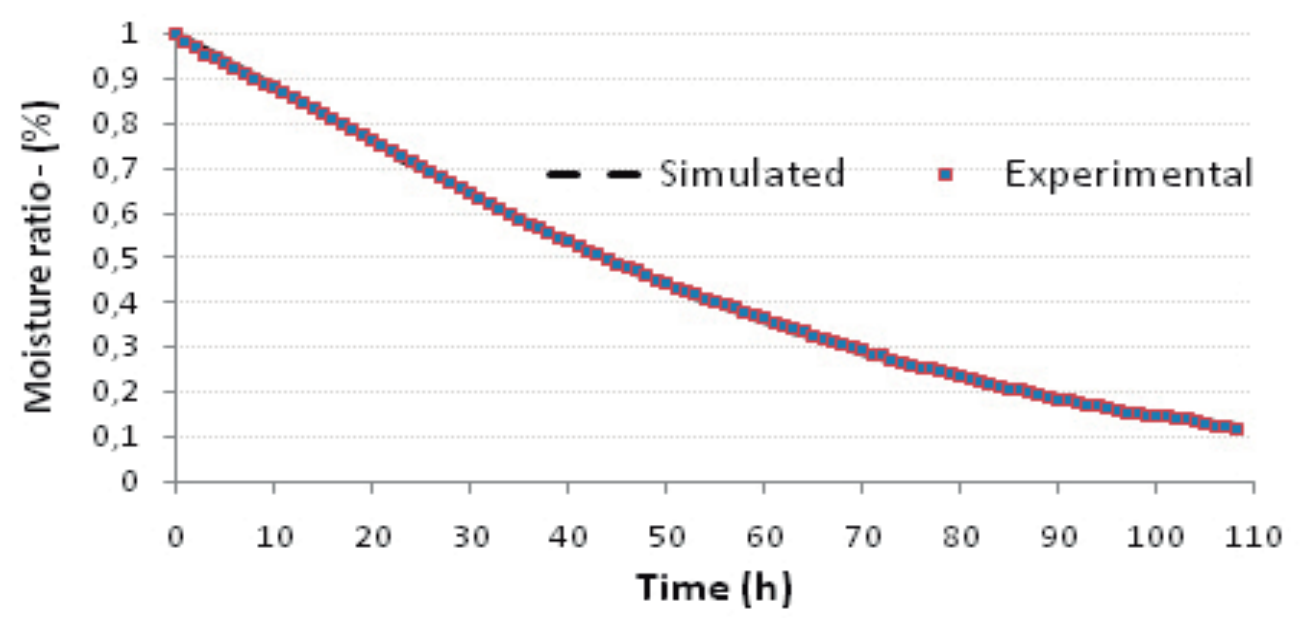

FIGURE 12 -Values of moisture ratio for the experimental data compared to simulated data.

\section{CONCLUSIONS}

According to the results obtained in this study, we conclude that:

- The model developed in a computational manner by the technique of computational fluid dynamics for drying natural coffee fruit satisfactorily fit the experimental data with a mean relative error of $1.8 \%$.

- For drying air temperature of $40^{\circ} \mathrm{C}$ and relative humidity of $25 \%$ at the end of drying, $57.1 \%$ of the area of projection of natural coffee fruit has moisture content below 0.18 decimal (d.b.).

- The effective diffusivity coefficient found by the model was $2.87 \times 10^{-11} \mathrm{~m}^{2} \mathrm{~s}^{-1}$.

\section{REFERENCES}

ALVES, G. E. et al. Cinética de secagem de café natural para diferentes temperaturas e baixa umidade relativa. Coffee Science, Lavras, v. 8, n. 2, p. 238-247, Apr./ June. 2013.

ANSYS 11: Manual Ansys. Ontario, 2008. Software.

BERGMAN, T. L. et al. Fundamentals of heat and mass transfer. New Jersey: John Wiley \& Sons, p. 625, 2011.

BORÉM, F. M. Pós-colheita do café. Lavras: Ed. Ufla. p. 225 a 237.2008. 
BRASIL. Ministério da Agricultura, Pecuária e Abastecimento. Regras para Análise de Sementes. Brasília, 2009. 399p.

Brooker, D. B.; Bakker-Arkema, F. W.; Hall.C. W. Drying and storage of grains and oilseeds. New York: Van Nostrand Reinold, 1992. 450p.

BURMESTER, K; EGGERS, R. Heat and mass transfer during the coffee drying process. Journal off Food Engeneering, Essex, v. 99, n. 4, p. 430-436, Aug. 2010.

CORRÊA, P. C.; MACHADO, P. F.; ANDRADE, E. T. Cinética de secagem e qualidade de grãos de milhopipoca. Ciência e Agrotecnologia, Lavras, v. 25, n. 1, p. 134-142, Jan./ Feb. 2001.

CRANK, J. The mathematics of diffusion. Oxford. Clarendon Press. 1975.

FILHO, L. C. C. et al. Cinética de secagem, contração volumétrica e análise da difusão líquida do figo (Ficus carica L). Revista Brasileira de Engenharia Agrícola e Ambiental, Campina Grande, v. 19, n. 8, p. 797-802, Aug. 2015.

FORTES, M. et al. Modelagem de um condicionador de ar de alta precisão para uso em processamento agrícola. Engenharia Agrícola, Jaboticabal, v. 26, n. 2, p. 578589, May./Aug. 2006.

INFORME ESTATÍSTICO DO CAFÉ. Outubro 2016. Available in: $<$ http://www.consorciopesquisacafe. com.br/index.php/imprensa/noticias/420Aprespdfviiispcb\#A>. Access on: 01 June 2018.

INTERNATIONAL ORGANIZATION FOR STANDARDIZATION. Green coffee: determination of loss in mass at $105^{\circ} \mathrm{C}$ : ISO 6673. Geneva, 2003. 17 p.

ISQUIERDO, E. P. et al. Drying Kinetics and quality of natural coffee. American Society of Agricultural and Biological Engineers. Transactions, v. 56, p. 10031010, 2013.
JÚNIOR, P. C. A. Aspectos físicos, fisiológicos e de qualidade do café em função da secagem e do armazenamento. 2001. Tese (Doutorado em Engenharia Agrícola) - Universidade Federal de Viçosa, Viçosa, 2001.

MADAMBA, P. S.; DRISCOLL, R. H.; BUCKLE, K. A. Thin layer drying characteristics of garlic slices. Journal of Food Engineering, v. 29, n. 1, p. 75-97, July. 1996.

MOHAPATRA, D.; RAO, P. S. A thin layer drying model of parboiled wheat. Journal of Food Engineering, London, v. 66, n. 4, p. 513-518, Feb. 2005.

NILNONT, W. et al. Finite element simulation for coffee (Coffeaarabica) drying. Food and Bioproducts Processing, v. 90, n. 2, p. 341-350, Apr. 2012.

RESENDE, O. et al. Modelagem matemática para a secagem de clones de café (Coffea canephora Pierre) em terreiro de concreto. Acta Scientiarum. Agronomy, Maringá, v. 31, n. 2, p.

189-196, Apr./June. 2009.

SAATH, R. et al. Microscopia eletrônica de varredura do endosperma de café (Coffea arabica L.) durante o processo de secagem. Ciência e Agrotecnologia, Lavravs, v. 34, n. 1, p. 196-203, Jan./Feb. 2010

SCHNEIDER, F. A.; MALISKA, C. R. Uma formulação em volumes finitos usando malhas nãoestruturadas. VIII ENCIT - Encontro Nacional de Ciências Térmicas, CD Romedition, 2000. Available in: <http://www.sinmec.ufsc.br/sinmec/site/iframe/ pubicacoes/artigos/novos_00s/2000_unstructured and_hybrid_grids.pdf $>$.

SILVA, J. A. et al. Analysis of effects of grain dust explosion using computational fluid dynamics. American Society of Agricultural and Biological Engineers, 2012. Dallas, Texas, July 29 - August, 2012.

SILVA, J. A.; GOMES, F. C.; CORREA, J. L. G. Analysis of the pressure effects in corn dust explosion using computational fluid dynamics. In: International Conference of Agricultural Engineering, 2012, Valência. International Conference of Agricultural Engineering. 2012. 